\title{
MINYAK GOSOK DAPAT MENGOBATI STOMATITIS APTOSA REKUREN SECARA TOPIKAL
}

\author{
Ali Yusran, Donald RN \\ Bagian Ilmu Penyakit Mulut \\ Fakultas Kedokteran Gigi Universitas Hasanuddin
}

\begin{abstract}
Many studies have been done to get the right material in the treatment of recurrent minor aphthous stomatitis, but the result still unsatisfied.

The aim ofthistudy was to know the influence application of rubbing oil against the healing and comportable at recurrent minor aphthous stomatitis. This study was a clinical observasionally and healing was resulted in about four days. The use of topical rubbing oil in the treatment of recurrent minor aphthous stomatitis could avoid infection.

Key Words: rubbing oil, recurrent stomatitis aphthous.
\end{abstract}

\section{PENDAHULUAN}

Stomatitis aptosa rekuren adalah suatu penyakit yang mempunyai gejala karakteristik berupa ulserasi rekuren yang terbatas pada mukosa mulut tanpa disertai tanda - tanda dari penyakit lain. Secara klinik penyakit ini dibagi menjadi tiga tipe berdasarkan ukuran dan kedalaman lesi yaitu tipe mayor, tipe minor dan herpetiformis. ${ }^{1}$ Stomatitis aptosa rekuren merupakan lesi yang bermanifestasi didalam rongga mulut, pada tipe yang parah dapat menimbulkan rasa sakit. ${ }^{2}$

Stomatitis aptosa rekuren dapat terjadi pada semua umur, predileksi pada wanita sekitar 50persen, berumur 10-19 tahun, dan sebanyak 90 persenpenderita stomatitis aptosa rekuren sebelum 
berumur 40 tahun. $^{3}$

Etiologi stomatitis aptosa rekuren hingga saat ini masih belum diketahui, namun sejumlah faktorfaktor predisposisi telah dapat diidentifikasi yaitu mikroorganisme, herediter, trauma, hormonal, defisiensi nutrisi, kelainan sistim pencernaan, psikososial dan kelainan imunologi. ${ }^{4}$

Oleh karena sifat-sifat penyakit stomatitis aptosa rekuren yang etiologinya belum jelas namun banyak faktor-faktor yang berpengaruh terhadap penyakit tersebut, maka peravvatan stomatitis aptosarekuren sering menimbulkan masalah, baik bagi dokter maupun penderita. Telah banyak penelitian yang dilakukan untuk mendapatkan bahan-bahan yang ampuh untuk menyembuhkan penyakit ini seperti Chlorhexidin, Albotil. $^{5}$ Namun hingga saat ini hasilnya belum memuaskan.

Stomatitis aptosa rekuren telah menjadi bahan penelitian dari berbagai aspek, termasuk epidemiologi, imunologi, korelasi klinis dan terapi. ${ }^{1}$
Anjuran dari Organisasi Kesehatan Dunia untuk menggalakkan kembali pemakaian obat tradisional dalam menjaga kesehatan masyarakat, maka pada saatnyalah Indonesia mengembangkan dan meningkatkan produksi dalam Negeri berupa obat tradisional dengan menerapkan IImu Pengetahuan dan Teknologi mutahir. Sejalan dengan anjuran Organisasi

Kesehatan Dunia. Direktorat Jenderal POM Departemen Kesehatan mengembangkan pro gram beberapa jenis obat tradisional agar dapat dijangkau oleh masyarakat menengah kebawah.

Guna menunjang program Pemerintah tersebut, Institusi Pendidikan sangat berkewajiban untuk melakukan penelitian IImiah terhadap obat tradisional yang banyak dipakai dan dijual bebas. ${ }^{6}$ Banyak ditemukan beredar dimasyarakat, minyak gosok dengan berbagai merek sebagai predikat obat tradisional yang dapat menyembuhkan berbagai macam 
luka, baik itu luka yang terdapat diluar mulut, maupun yang terdapa didalam mulut.

Bagi sebagian besar masyarakat di Indonesia, obat tradisional ini telah digunakan secara turun temurun untuk menyembuhkan berbagai macam penyakit atau luka.Namun demikian pemakaian minyak tersebut khususnya dalam mulut belum dapat dipertanggung jawabkan secara medis. Sebagaimana disebutkan sebelumnya bahwasanya Minyak gosok terdiri dari piperis fo lium (sirih) yang bersifat mencegah super infeksi dan mempunyai kasiat, terhadap lesi-lesi didalam mulut.

Curcumae rhizoma dan atrium sativum memiliki sifat anti septik, sedang champora adalah anti piretik, kemudian kandungan mentol memberi rasa sega dannyaman.

Tyldesley $^{7} \quad$ Mengatakan bahwa pengobatan yang direkomendasikan untuk stomatitis aptosa yang rekuren adalah penggunaan anti bakteri, anti septik dan anti inflamasi secara topikal.

Penyakit stomatitis aptosa rekuren merupakan proses radang kronik dan menimbulkan rasa sakit dalam mulut, maka sifat-sifat bahan yang terkandung didalam minyak tawon ini dapat digunakan dalam perawatan stomatitis aptosa rekuren.

Penelitian ini untuk mengetahui penyembuhan yang disertai rasa nyaman didalam mulut dengan aplikasi minyak gosok secara topikal pada stomatitis aptosa minor yang rekuren.

\section{BAHAN DAN CARA}

Penelitian ini merupakan penelitian observasional klinis dan analisis secara deskriptif dengan mengamati fenomena kesehatan pada jaringan lunak secara objektif. Penelitian dilakuan pada bulan Agustus sampai dengan bulan Oktober tahun 2001 dan bertempat di Poliklinik Ilmu Penyakit Mulut Fakultas Kedokteran Gigi Universitas Hasanuddin Makassar. Subjek penelitian adalah 
Mahasiswa fakultas kedokteran gigi Unhas sebanyak 34 orang, kemudian dibagikan obat minyak gosok cap tawon setiap subjek, dengan kriteria menderita stomatitis aptosa rekuren minor setiap bulan, minimal pemah mengalami tiga kali sebelum pengambilansampel dan selama masa penelitian subjek tersebut tidak menggunakan obat stomatitis, antibiotik, analgesik, anti inflamasi, antipiretik dan obat lain yang berhubunganterhadap proses penyembuhan. Pada stomatitis aptosa rekuren yang ringan, dapat sembuh sendiri tanpapengobatan dalam waktu satu mingga ${ }^{1}$

Data yang telah dikumpulkan dievaluasi untuk menilai dan mengamati penyembuhan, dengan cara mengukur waktu penyembuhan dengan kategori sebagai berikut:

- Ledih cepat yaitu kurang dari empat hari ( $<4$ hari).

- Tetap yaitu empat sampai enam hari (4-6 hari).

- Lebih lama yaitu enam hari keatas ( $>6$ hari)

Menilai kenyamanan dengan kategori sebagai berikut:

- Rasa Nyaman yaitu dapat memberikan rasa segar atau dingin dalam mulut.

- Tidak ada rasa yaitu tidak ada perbedaan pada saat pemberian maupun sebelum pemberian.

- Rasa tidak enak yaitu memberikan rasa yang kurang nyaman baik itu rasa mual dan lain sebagainya dalam mulut.

Data hasil penelitian didiskripsikan dan disajikan dalam bentuk tabel.

\section{Cara kerja}

Pemeriksaan secara klinis pada mukosa mulut (dimulai dengan gejala prodromal) rasaterbakar setiap waktu mulai dari 2 sampai 48 jam sebelum munculnya ulser, selama periode pendahuluan ini, akan terbentuk suatu daerah kemerahan setempat, subjek penelitian yang memenuhi kriteria dilakukan pendataan, hasil pemeriksaan dicatat pada kartu status dan diberi minyak gosok kemudian di instruksikan penggunaannya yaitu tiga kali sehari atau paling sedikit dua kali sehari 
dan diolesi sebelum sikatgigi

\section{HASIL}

Berdasarkan hasil penelitian dan pengamatan maka diperoleh hasil sebagai berikut:

Dari tabel 1 terlihat bahwa 53\% (18 orang) sampel yang ada mengalami proses penyembuhan stomatitis aptosa rekuren kurang dari 4 hari dan 35\% (12 orang) berlangsung 4 sampai dengan 6 hari serta 12\% (4 orang) berlangsung lebih dari 6 hari. Hal tersebut menujukkan bahwa sebagian besar sampel mengalami remisi penyembuhan penyakit stomatitis aptosa rekuren setelah pengolesan, pemberian minyak gosok cap tawon kurang dari 4 hari.

Dari tabel 2 diatas, terlihat bahwa $75 \%$ (26 orang) dari sampel tersebut yang ada lebih merasa nyaman setelah aplikasi secara topikal minyak gosok cap tawon, sedangkan 9\% (3 orang) merasa tidak enak, hal tersebut dikarenakan adanya kandungan minyak, dan $15 \%$ mengatakan tidak ada rasa sama sekali setelah pengolesan minyak tawon tersebut.

Hal ini menunjukkan bahwa pengolesan atau aplikasi secara topikal minyak gosok cap tawon lebih memberikan rasa nyaman pada pasien yang ada.

\section{PEMBAHASAN}

Pemberian zat besi, folat atau vitamin B12, merupakan indikasi, serta hampir dapat dipastikan memberi efek yang menguntungkan. tetapi untuk pasien yang tidak kekurangan zat tersebut, perawatan tersebut kurang bermanfaat, sehingga dapat dilakukan cara perawatan yang lain, untuk menghilangkan kelainan ini. Hanya sedikit cara perawatan yang sudah terbukti secara klinis dapat bermanfaat. ${ }^{8}$

Penelitian stomatitis aptosa rekuren merupakan suatu bentuk keradangan dirongga mulut yang mana lesinya berupa ulser. Kelainan ini sering dijumpai dimana pasien merasa kesakitan 
Tabel 1. Sebaran hasil pengamatan klinis penderita stomatitis aptosa rekuren yang diberi minyakgosok berdasarkan waktu penyembuhan

\begin{tabular}{lllll}
\hline Jumlah sampel & \multicolumn{3}{c}{ Waktu penyembuhan } & \\
\hline & $<4$ hari & $4-6$ hari & $>6$ hari & \\
\hline & $18(53 \%)$ & $12(35 \%)$ & $4(12 \%)$
\end{tabular}

Tabel 2. Sebaran hasil pengamatan klinis penderita stomatitis aptosa rekuren yang diberi minyak "gosok berdasarkan kenyamanan.

\begin{tabular}{ccccc}
\hline Jumlah sampel & & & Ke n y a m a n a n & \\
\hline & & Rasa nyaman & Tidak ada rasa & Rasa tidak enak \\
34 & & $26(76 \%)$ & $5(15 \%)$ & $3(9 \%)$ \\
\hline
\end{tabular}

yang luar biasa dan bahkan dapat mengalamikesulitan pada proses pengunyahan, bicara serta kesulitan untuk membersihkan gigi dan mulut. Pada daerah yang mengalami keradangan terjadi berbagai perubahan antara lain melebarnya pembuluh darah kapiler, sehingga menyebabkan volume darah meningkat dan menjadikan pembuluh darah lebih permiabel juga terjadi migrasi leukosit keluar dari pembuluh darah dan menembus jaringan disertai kerusakanjaringan.

Penggunaan anti bakteri, anti septik atau anti inflamasi secara topikal dalam pengobatan stomatitis aptosa rekuren bertujuan untuk mencegah infeksi sekunder. ${ }^{7}$

Pemilihan minyak gosok cap tawon sebagai obat tradisional dalam pengobatan secara topikal stomatitis aptosa rekuren adalah karena bahan aktif yang terkandung dalam minyak gosok cap tawon seperti piperis folium merupakan sumber dari sirih dan dapat mencegah super infeksi. Tyldesley mengatakan bahwa pengobatan yang dianjurkan untuk stomatitis aptosa rekuren adalah penggunaan anti bakteri, anti septik dan inflamasi secara topikal. ${ }^{7}$ Berdasarkan hasilpengamatan dalam penelitian ini bahwa 53\% (18 orang) dari sampel yang ada mengalami penyembuhan kurang dari 4 hari, 
sedangkan $35 \%$ atau 12 orang yang berlangsung 4-6 hari, kemudian $12 \%$ (4 orang) mengalami proses penyembuhan lebih dari 6 hari, hal ini menunjukkan bahwa dengan pengolesan minyak gosok cap tawon pada lesi stomatitis aptosa rekuren dapat mengurangi waktu penyembuhan. Prabowo melaporkan bahwa terapi stomatitis aptosa rekuren dengan menggunakan madu secara topikal menunjukkan waktu penyembuhan yang lebih cepat dibanding tanpa perawatan. $^{8}$

Stomatitis aptosa rekuren telah menjadi bahan penelitian dari berbagai aspek, termasuk epidemiologi, imunologi, korelasi klinis dan terapi prevalensi stomatitis aptosa rekuren cukup tinggi, terbukti dari hasil penelitian beberapa bagian dunia menunjukkan bahwa prevalensi stomatitis aptosa rekuren sangat bervariasi, yaitu $17-66 \%$ dari populasi.

\section{KESIMPULAN}

Dari hasil penelitian dan pembahasan diatas menyimpulkan bahwa minyak gosok cap tawon dapat digunakan sebagai pengobatan alternatif pada stomatitis aptosa rekuren karena mempu-nyai bahan aktif sebagai anti infeksi, anti septik serta anti piretik dan sekaligus mempunyai efek rasa nyaman atau rasa segar setelah diaplikasikan.

\section{SARAN}

Diharapkan penelitian lebih lanjut untuk menguji efektifitas secara klinis dalam proses penyembuhan.

\section{DAFTARPUSTAKA}

1. Lync MA, Braghman VJ, Greenberg MS. Oral Medicine Diagnosis and Tretment. 9 Ed. JB Lippincott Co. Philadelphia. London. New York. 1994. 24-29.

2. Pitojo S. Keterlibatan Infeksi Bakteriologik pada Stomatitis Aphtous dan Peranan Anti Mikroba pada Pengobatannya, Kumpulan Makalah IImiah, FKGUSU, Medan. 1991. 48-51.

3. Sonis. Principles and Practice of 
Oral Medicine, W.B. Saunders Company. Philadelphia 1984.442.

4. Rennie JS. Recurrent apthous stomatitis. J British Dent. 1995; 1085 : 361-366.

5. Vincent, SD; Lily, GE. Clinical Historic and

6. Therapeutic Features of Aphtous Stomatitis and Behcet Syndrome. Oral Surgery. Oral Med. Oral Pathology. 1992. 74:79-86.
7. Hutapea. Kembali ke Obat Nenek Moyang. Majalah D\&R. Maret. 1998. 9-11. :

8. Tyldesley WR. Oral Medicine. Toronto. Ox-

9. ford Univercity Press. 1981. 4661.

10.8. Prabowo SW. Efek terapi madu topikal terhadap kesembuhan stomatitis aphtous rekuren. Surabaya. Skripsi FKG Unair. 1996. 